\title{
DEGREE OF SATISFACTION WITH THE ENDOSCOPIC TREATMENT OF LUMBAR DISC HERNIATION
}

\author{
GRAU DE SATISFAÇÃO NO TRATAMENTO ENDOSCÓPICO DE HÉRNIA DE DISCO LOMBAR \\ GRADO DE SATISFACCIÓN CON EL TRATAMIENTO ENDOSCÓPICO DE HERNIA DE \\ DISCO LUMBAR
}

Cristiano Gatelli ${ }^{1}$ Xavier Soler Graells ${ }^{1}$, Álynson Larocca Kulcheski ${ }^{1}$, Marcel Luiz Benato ${ }^{1}$, Pedro Grein Santoro ${ }^{1}$

1. Hospital do Trabalhador, Spine Surgery, Curitiba, PR, Brazil.

\begin{abstract}
Objective: To evaluate the degree of patient satisfaction and complications after endoscopic surgery for the treatment of lumbar disc herniation. Methods: We retrospectively evaluated 94 patients with lumbar disc herniation undergoing endoscopic lumbar discectomy through the MacNab questionnaire and four subjective questions related to the procedure. Results: Approximately $82 \%$ of the patients had good and excellent results, and $91.4 \%$ reported being satisfied with the surgical result obtained with endoscopy. The rate of complications with the method was 9.5\%, with recurrent disc herniation being the most common complication (5.4\% of cases). Conclusions: Endoscopic surgery proved to be an effective and safe method, and an alternative to conventional open surgery. Level of evidence; III. Therapeutic studies - Investigation of treatment results.
\end{abstract}

Keywords: Spine; Endoscopy; Sciatica; Complications.

\section{RESUMO}

Objetivo: Avaliar o grau de satisfação dos pacientes e as complicações após cirurgia endoscópica para tratamento da hérnia discal lombar. Método: Avaliados, retrospectivamente, 94 pacientes com hérnia discal lombar, submetidos a discectomia lombar endoscópica, através do Questionário MacNab e por meio de quatro perguntas subjetivas relacionadas ao procedimento. Resultados: Aproximadamente $82 \%$ dos pacientes tiveram excelentes e bons resultados e 91,4\% relataram estar satisfeitos com o resultado cirúrgico obtido com a endoscopia. A taxa de complicações com o método foi de 9,5\%, sendo a recidiva da hérnia discal a complicação mais comum (5,4\% dos casos). Conclusão: A cirurgia endoscópica se mostrou um método eficaz, seguro e uma alternativa à cirurgia aberta convencional. Nível de evidência; III. Estudos terapêuticos - Investigação dos resultados do tratamento.

Descritores: Coluna vertebral; Endoscopia; Ciática; Complicações.

\section{RESUMEN}

Objetivo: Evaluar el grado de satisfacción de los pacientes y las complicaciones después de la cirugía endoscópica para el tratamiento de hernia de disco lumbar. Métodos: Se evaluaron retrospectivamente 94 pacientes con hernia de disco lumbar sometidos a discectomía lumbar endoscópica a través del cuestionario MacNab y de cuatro preguntas subjetivas relacionadas con el procedimiento. Resultados: Aproximadamente el $82 \%$ de los pacientes tuvieron buenos y excelentes resultados y el 91,4\% relató estar satisfechos con el resultado quirúrgico obtenido con la endoscopia. La tasa de complicaciones con el método fue del 9,5\%, siendo la recidiva de la hernia de disco la complicación más común (5,4\% de los casos). Conclusiones: La cirugía endoscópica demostró ser un método eficaz, seguro y una alternativa para la cirugía abierta convencional. Nivel de evidencia; III. Estudios terapéuticos - Investigación de los resultados del tratamiento.

Descriptores: Columna vertebral; Endoscopía; Ciática; Complicaciones.

\section{INTRODUCTION}

Lumbosciatalgia is one of the most common complaints in orthopedic practice and approximately $5 \%$ of the cases seen result from disc herniation. According to the natural history of disc herniation, around $95 \%$ of patients improve completely after three months of conservative treatment. ${ }^{1,2}$

Patients who are refractory to clinical treatment or who present progressive neurological worsening have the therapeutic option of surgical intervention. ${ }^{1}$ Among surgical treatments, the open microdiscectomy is considered the gold standard. . $^{1,3,4}$

With technology advances and the interest in making modern surgical treatment techniques available, minimally invasive surgeries have been developed. ${ }^{3,5,6}$ Despite the fact that less invasive techniques have a long learning curve, higher cost, and longer surgical time, this treatment is the trend and literature data have shown that this method is safe, and its indication is increasing in as the technique gains acceptance..$^{3,6-10}$

Minimally invasive spinal surgery has gradually evolved, endoscopic equipment being improved and demonstrating progressive success and, currently, two percutaneous decompression techniques are the most used: transforaminal, described in 2004 by Tsou and Yeung, and interlaminar, described by Choi in $2005 .^{7}$

The advantages of using minimally invasive techniques are a smaller surgical incision and less aggression of the soft tissues (multifidus 
muscles, ligaments, and the facet joint capsules). Less aggression generates less local pain, in addition to using minimal bone resection for the discectomy, which can prevent possible spinal instability. $6,9,11-16$

The objective of this study was to evaluate the surgical results obtained using endoscopic discectomy to treat lumbar disc herniation and the complications associated with the method.

\section{METHODS}

This was a retrospective descriptive study, approved by the Institutional Review Board of the Hospital do Trabalhador as CAAE number 64275817.3.0000.5225. Data was collected from 94 patients who underwent endoscopic surgery (transforaminal or interlaminar) at the Hospital do Trabalhador, Curitiba-PR, during the period from January 2104 to December 2016. The interlaminar approach was indicated for patients with central or central-lateral herniations, while we opted for the transforaminal approach in patients with foraminal and extraforaminal herniations. The clinical assessment was conducted by means of the MacNab questionnaire, ${ }^{17}$ with the addition of four yes or no questions to be answered by the patients, as shown in Table $1 .{ }^{18}$

Epidemiological data such as age, sex, return to work, were evaluated together with postoperative complications, including infection of the surgical site, neurological changes (pareses, paresthesias), neural lesions, and iatrogenic durotomy. We also collected data about recurrence of the disc herniation.

Patients previously submitted to surgical spinal treatment for any other reason, those below 18 or above 80 years of age, those with postoperative follow-up less than 6 months, and those who did not sign the informed consent form were excluded. All patients participating in this research signed the informed consent form.

\section{RESULTS}

Ninety-four patients who underwent endoscopic surgical treatment for lumbar disc herniation were included in this study. Fifty-two (55.3\%) patients were female and 42 (44.7\%) were male. Their ages ranged from 18 to 79 years, with a mean of 39 years of age. Of these patients, seventy-eight (82.9\%) were treated using the interlaminar technique and $16(17.1 \%)$ with the transforaminal technique. (Figure 1) A total of 116 levels were operated, with L5-S1 being the most often involved at 62 (53.4\%), followed by L4-L5 at 49 (42.2\%), and L3-L4 at 5 (4.3\%). Mean follow-up up was 14 months (6-34 months). (Figure 2)

According to the results of the MacNab questionnaire, 53 (56.3\%)

Table 1. Questionnaire given to the patients.

Since the endoscopic surgery, have you had lumbar symptoms at the same level?

Are you satisfied with the results of the endoscopic surgery?

Based on your experience, would you undergo the same endoscopic surgery in the future or recommend it to someone you know? Did your spine or leg symptoms worsen following surgery?

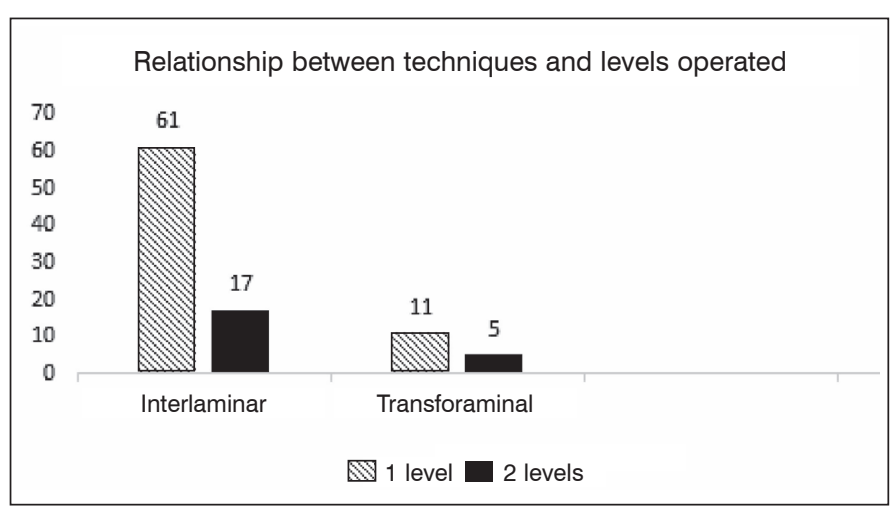

Figure 1. 1- and 2-level interlaminar and transforaminal approaches. cases were assessed as excellent, 24 (25.4\%) as good, 12 (12.7\%) as fair, and $5(5.4 \%)$ as poor. (Figure 3 ) In terms of the questions, $68(72.3 \%)$ patients reported that they had no more symptoms at the same levels as previously operated. Eighty-six (91.4\%) said they were satisfied with the results obtained with endoscopy. Eighty-nine $(94.6 \%)$ would undergo the procedure again or would indicate it to someone they knew. In 5 (5.4\%) cases the symptoms worsening following surgery, coinciding with the patients with poor MacNab assessments, and presenting statistical significance in the Fisher exact test $(p<0.001)$. (Table 2$)$

We observed that $9(9.5 \%)$ cases presented complications. No case of total neurological lesion was reported, however, we had 4 $(4.2 \%)$ cases of dyspraxia that evolved with improvement of the condition in the third month following surgery. Two (2.1\%) patients had large herniated volume and continued to complain of postoperative sciatalgia. Magnetic resonance was performed and we observed insufficient removal of the herniated content in one of them and the other underwent endoscopic revision surgery. Two cases (2.1\%) presented lesions of the dura mater, which did not progress to cerebrospinal fluid fistulas and improved clinically following conservative treatment. One case (1.06\%) progressed with discitis and an epidural abscess, requiring surgical debridement, open compression, and posterior approach arthrodesis. Five (5.4\%) patients suffered relapse and needed revision with open decompression and posterior approach arthrodesis.

As regards return to work, 68 (72.3\%) patients returned to work and $26(27.6 \%)$ did not return. Of those who did not return, seven $(7.4 \%)$ were involved in labor grievances, two (2.1\%) were retired, eight (8.5\%) had recurrences/complications, and 10 (10.6\%) patients had no complications, but had been evaluated as MacNab 3 or 4 , and were on leave receiving benefits. (Figure 4)

\section{DISCUSSION}

The gold standard treatment for lumbar disc herniation is open microdiscectomy, however, with advances in medicine and in minimally

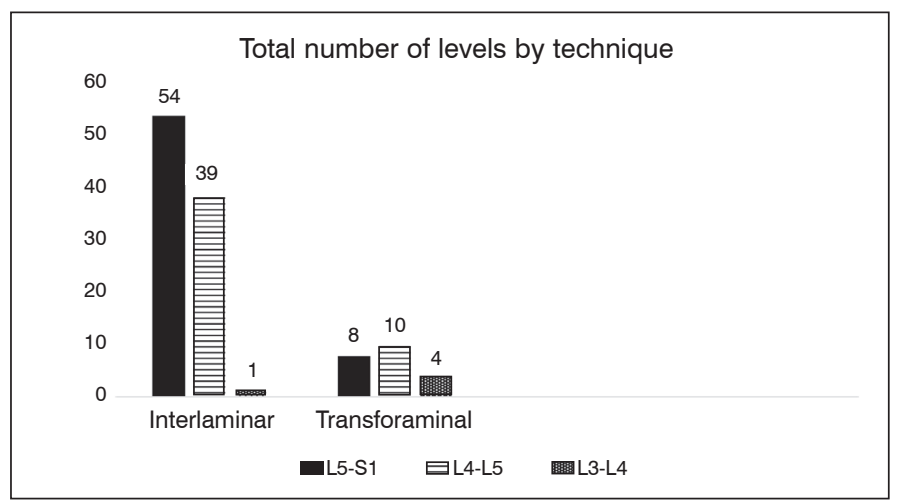

Figure 2. Total number of levels operated by technique used.

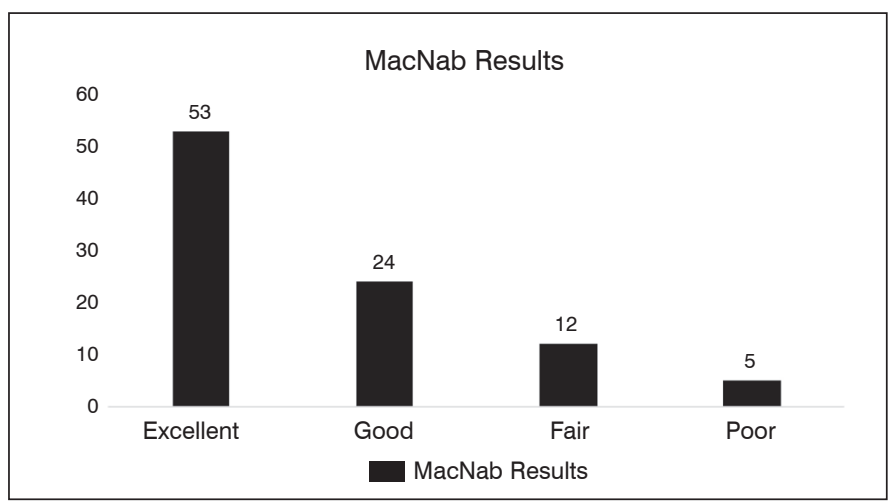

Figure 3. Patient satisfaction index according to the MacNab questionnaire. 
Table 2. Results from the questions asked.

\begin{tabular}{c|c|c}
\hline Questions & Yes & No \\
\hline $\begin{array}{c}\text { Since the endoscopic surgery, have you had } \\
\text { lumbar symptoms at the same level? }\end{array}$ & $26(27.7 \%)$ & $68(72.3 \%)$ \\
\hline $\begin{array}{c}\text { Are you satisfied with the results of the } \\
\text { endoscopic surgery? }\end{array}$ & $86(91.4 \%)$ & $8(8.6 \%)$ \\
\hline $\begin{array}{c}\text { Based on your experience, would you undergo } \\
\text { the same endoscopic surgery in the future or } \\
\text { recommend it to someone you know? }\end{array}$ & $89(94.6 \%)$ & $5(5.4 \%)$ \\
\hline $\begin{array}{c}\text { Did your spine or leg symptoms worsen } \\
\text { following surgery? }\end{array}$ & $5(5.4 \%)$ & $89(94.6 \%)$ \\
\hline
\end{tabular}

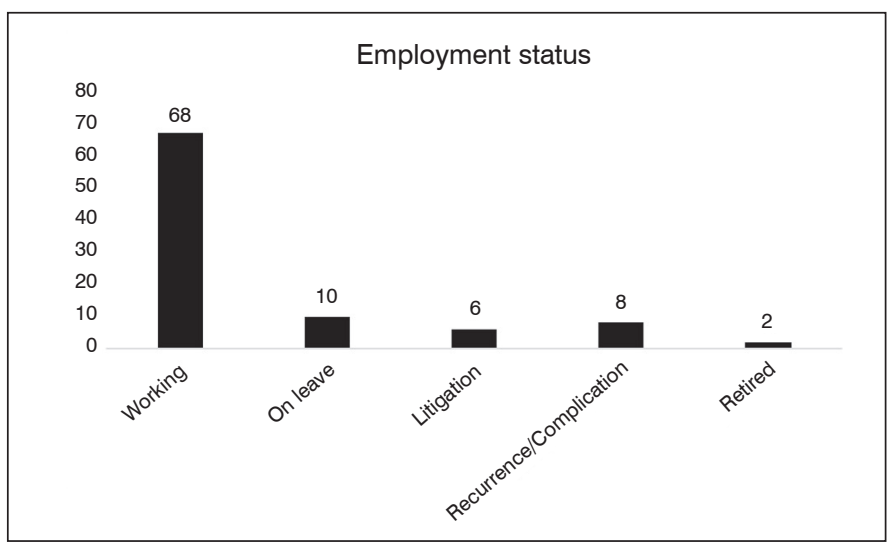

Figure 4. Employment status following surgery.

invasive techniques, modern discectomy techniques have recently gained popularity, as is the case with endoscopic surgery. ${ }^{17-19}$

In this study, we conducted a retrospective evaluation of patients submitted to endoscopic surgery with an average follow-up of 14 months, ranging from 6 to 34 months. Using the MacNab questionnaire, approximately $82 \%$ of the patients had excellent and good results, similar to open technique success rates in the literature that range from 70 to $84 \%$ good results. ${ }^{20}$ Ruetten et al and Yeung and Tsou observed $85 \%$ and $81 \%$, respectively, for the same technique, corroborating our findings. ${ }^{9,12}$ As regards the questions related to satisfaction with the surgical result, $91.4 \%$ of the patients reported being satisfied with the result obtained and $94.6 \%$ would undergo the procedure again if necessary or would indicate it for someone who needs it. Only 5 (5.4\%) cases whose symptoms worsened would not indicate the surgery or would not do it again. In similar questionnaires, Yeung and Tsou obtained $90.7 \%$ and Choi et al. $90.8 \%$ satisfaction among the operated patients. ${ }^{9,12,13,15}$
The overall complications rate in our study was $9.5 \%$, lower than that of the gold standard technique at $12.5 \%{ }^{14}$ We observed no complete neurological injury, however, we had $4.2 \%$ of cases with dyspraxia that evolved with improvement by the third month following surgery. In a study published by Choi et al., the authors reported $12 \%$ of patients with this complication, with improvement of the condition occurring during the first month of follow-up. ${ }^{15}$

Transoperative durotomy occurred in two cases (2.1\%), less than the results for the open technique reported by Desai et al., ${ }^{21}$ who observed $3.1 \%$ with this complication. Our cases did not require repair and did not progressed to cerebrospinal fluid fistulas during follow-up, and were treated conservatively with 48 hours in dorsal decubitus, restricted fluids, and analgesic medications. The literature reports an incidence of between 1 and $17 \%$ of dural lesions, depending on the patient and on the procedure performed. ${ }^{14}$

We did not observe complications with the surgical wound, however, one patient evolved with an infection of the disc space and an epidural abscess, which required ample posterior decompression with drainage and arthrodesis. Yeung and Tsou had two cases of pyogenic discitis in their study of 307 patients. ${ }^{12}$

The recurrence rate was 5.4\%. All patients underwent open surgical decompression followed by posterior approach arthrodesis. In a meta-analysis by Shriver et al, recurrences of $4.4 \%, 3.1 \%$, and $3.9 \%$ were observed for the open technique, endoscopic microdiscectomy, and percutaneous microdiscectomy, respectively. ${ }^{14}$ Ruetten et al. reported recurrence of $6.2 \%{ }^{21}$ Similar relapse rates are shared by other authors. ${ }^{3,12,22}$

In this study we observed complications reported in other studies, such as thrombophlebitis, urinary retention, excessive bleeding, hematoma, seroma, and complete nerve root lesion. 9,11,12,14,15, 21

The return to work rate was $72.3 \%$. In a multicenter study, Kahanovitz et al. reported a return to work rate of $55 \%$. Pimenta et al. observed $80.6 \%$ return to work. ${ }^{10,23}$

\section{CONCLUSION}

Endoscopic surgery for the treatment of lumbar disc herniation presented $82 \%$ excellent and good results as evaluated by the MacNab questionnaire and $91.4 \%$ of the patients reported being satisfied with the surgical outcome. The option to use minimally invasive techniques is a trend in medicine and endoscopic surgery has proven to be a safe and effective technique with results that are comparable to the traditional approach.

All authors declare no potential conflict of interest related to this article.

CONTRIBUTION OF THE AUTHORS: Each author made significant individual contributions to this manuscript. CG (0000-0002-3709-2880)*, XSG $(0000-0002-9636-9165)^{\star}$, and ALK (0000-0002-0132-6083)* were the main contributors to the writing of the manuscript. ALK performed the surgeries ALK, PGS (0000-0002-8326-4823)*, and CG conducted patient follow-up and collected the clinical data from the medical records together with XSG and MLB (0000-0002-2903-8550*), who also evaluated the statistical analysis data. CG, XSG, and ALK conducted the bibliographical research, reviewed the manuscript, and contributed to the intellectual concept of the study. ${ }^{*} \mathrm{ORCID}$ (Open Researcher and Contributor ID).

\section{REFERENCES}

1. Benzel EC. Spine surgery: techniques, complication avoidance, and management. London: Churchill Livingstone; 2005

2. Canale ST, Beaty JH. Campbell's operative orthopaedics. London: Elsevier Health Sciences; 2012.

3. Chen HT, Tsai CH, Chao SC, Kao TH, Chen YJ, Hsu HC, et al. Endoscopic discectomy of L5-S1 disc herniation via an interlaminar approach: Prospective controlled study under local and general anesthesia. Surg Neurol Int. 2011:2:93.

4. Kim HS, Park JY. Comparative assessment of different percutaneous endoscopic interlaminar lumbar discectomy (PEID) techniques. Pain physician. 2013;16(4):359-67.
5. Hsu HT, Chang SJ, Yang SS, Chai CL. Learning curve of full-endoscopic lumbar discectomy. Eur Spine J. 2013;22(4):727-33.

6. Choi G, Lee SH, Nicolau RJ. Discectomia endoscópica percutânea lombar (DEPL). Coluna/Columna 2008:7(2):177-82.

7. Nellensteijn J, Ostelo R, Bartels R, PeulW, Royen B, Tulder M. Transforaminal endoscopic surgery for symptomatic lumbar disc herniations: a systematic review of the literature. Eur Spine J. 2010;19(2):181-204

8. Pachicano HHA, Trujillo AR. Treatment of lumbar hernias by endoscopic nucleopasty with radiofrequency. Coluna/Columna. 2016;15(1):36-9. 
9. Ruetten S, Komp M, Merk H, Godolias G. Full-endoscopic interlaminar and transforaminal lumbar discectomy versus conventional microsurgical technique: a prospective, randomized, controlled study. Spine (Phila Pa 196). 2008;33(9):931-9.

10. Pimenta LHM, Tella OI, Zanetti R, Sutterlin C. Videoendoscopia via posterior para cirurgia de hérnia de disco lombar. Arq Bras Neurocir. 1999;18(1):11-6.

11. Hirano Y, Mizuno J, Takeda M, Itoh Y, Matsuoka H, Watanabe K. Percutaneous endoscopic lumbar discectomy —early clinical experience. Neurol Med Chir (Tokyo). 2012;52(9):625-30.

12. Yeung AT, Tsou PM. Posterolateral endoscopic excision for lumbar disc herniation: surgical technique, outcome, and complications in 307 consecutive cases. Spine (Phila Pa 1976). 2002;27(7):722-31.

13. Choi KC, Kim JS, Ryu KS, Kang BU, Ahn Y, Lee SH. Percutaneous Endoscopic Lumbar Discectomy for L5-S1 Disc Herniation: Transforaminal versus Interlaminar Approach. Pain Physician. 2013;16(6):547-56.

14. Shriver MF, Xie JJ, Tye EY, Rosenbaum BP, Kshettry VR, Benzel EC, et al. Lumbar microdiscectomy complication rates: a systematic review and meta-analysis. Neurosurg Focus. 2015;39(4):E6.

15. Choi G, Lee SH, Raiturker PP, Lee S, Chae YS. Percutaneous endoscopic interlaminar discectomy for intracanalicular disc herniations at L5-S1 using a rigid working channel endoscope. Neurosurgery. 2006;58(1 Suppl):ONS59-68.
16. Ikuta K, Tono O, Sanba H, Kitaura T, Komiya N, Oga M, et al. Translaminar microendoscopic herniotomy for cranially migrated lumbar disc herniations encroaching on the exiting nerve root in the preforaminal and foraminal zones. Asian Spine J. 2013; 7(3):190-5.

17. Anderle DV, Joaquim AF, Giglio MV, Ghizoni E, Esteves LA. Microdiscectomia lombar tubular com o uso de seringas descartáveis de diâmetros progressivos: resultados cirúrgicos. Coluna/Columna. 2010;9(2):145-9.

18. Castilho AM, Ghedini DF, Leal JS, Resende RLC, Gressler V. Discectomia lombar totalmente endoscópica. Coluna/Columna. 2016;15(4).

19. Apostolides PJ, Jacobowitz R, Sonntag VK. Lumbar discectomy microdiscectomy: "the gold standard". Clin Neurosurg. 1996:43:228-38.

20. Dohrmann GJ, Mansour N. Long-termresultsofvarious operations for lumbar disc herniation: analysis of over 39,000 patients. Med Princ Pract. 2015;24(3):285-90.

21. Desai A, Ball PA, Bekelis K, Lurie JD, Mirza SK, Tosteson TD, et al. Outcomes after incidental durotomy during first-time lumbar discectomy. J Neurosurg Spine. 2011;14(5):647-53.

22. Alvarenga MAM, Rocha TAF, Marchi L, Correia LS. Cirurgia totalmente videoendoscópica interlaminar para tratamento de hérnia de disco lombar-série de 50 casos. Arq Bras Neurocir. 1977;26(5):39-44.

23. Kahanovitz N, Viola K, Goldstein T, Dawson E. A multicenter analysis of percutaneous discectomy. Spine (Phila Pa 1976). 1990;15(7):713-5. 